\title{
HLA-C Gene
}

National Cancer Institute

\section{Source}

National Cancer Institute. HLA-C Gene. NCI Thesaurus. Code C62758.

This gene plays a role in both immune responses and histocompatibility processes. 